\title{
Postharvest Low Temperature Conditioning Reduces Peel Browning and Improves Fruit Quality in Storage and Subsequent Shelf Life of Huangguan Pear
}

\author{
Qingmin Chen ${ }^{1}$, Qingguo Wang2 ${ }^{*}$, Maorun $\mathrm{Fu}^{\mathbf{3}}$ \\ ${ }^{1}$ Department of Food Science and Engineering, College of Shandong Agricultural and Engineering, Ji'nan, \\ China \\ ${ }^{2}$ College of Food Science and Engineering, Shandong Agricultural University, Tai'an, China \\ ${ }^{3}$ College of Food Science and Engineering, Qilu University of Technology, Ji'nan, China \\ Email: "skyfmr@163.com
}

Received 23 September 2015; accepted 9 November 2015; published 12 November 2015

Copyright (C) 2015 by authors and Scientific Research Publishing Inc.

This work is licensed under the Creative Commons Attribution International License (CC BY).

http://creativecommons.org/licenses/by/4.0/

(c) (i) Open Access

\section{Abstract}

Huangguan pear (Pyrus bretschneideri Rehd cv. Huangguan) is a pear cultivar that rapidly developed in China. However, rapid postharvest browning appearing in fruit peel and core during storage and shelf life pose a challenge for their marketing. The potential for low temperature conditioning (LTC) treatment to inhibit peel browning and improve quality of Huangguan pears in storage and shelf life was investigated. Pears were treated at $8^{\circ} \mathrm{C}-9^{\circ} \mathrm{C}$ for $1,3,6$ and $9 \mathrm{~d}$, respectively, physiological indexes, including peel and core browning, core breakdown, malondialdehyde (MDA) content and ethanol content were determined and quality in storage period and shelf life was evaluated in this paper. LTC treatment alleviated peel browning and core browning either in storage or shelf life remarkably; it also delayed the decline of firmness, total soluble solids and titratable acidity in storage to some extent, inhibited ethanol and MDA content both in storage and shelf life effectively and maintained juiciness and crispness of pear fruit in shelf life. These results showed that LTC can serve as an important tool for the regulation of Huangguan pears external and internal quality in storage and shelf life with economic benefits and LTC treatment for $6 \mathrm{~d}$ was the optimum condition in the present study.

\section{Keywords}

Huangguan Pear, Low Temperature Conditioning, Peel Browning, Sensory Quality, Physiological

\footnotetext{
"Corresponding author.
}

How to cite this paper: Chen, Q.M., Wang, Q.G. and Fu, M.R. (2015) Postharvest Low Temperature Conditioning Reduces Peel Browning and Improves Fruit Quality in Storage and Subsequent Shelf Life of Huangguan Pear. Food and Nutrition Sciences, 6, 1351-1361. http://dx.doi.org/10.4236/fns.2015.615141 


\section{Disorder}

\section{Introduction}

Huangguan pear (Pyrus bretschneideri Rehd cv. Huangguan) is a pear cultivar that rapidly developed in northern China in recent years [1] [2]. Because of its thin peel, crisp flesh, rich juice, and good taste of moderate sweet-sour ratio [3], it has become more popular among consumers. However, rapid postharvest browning appearing in fruit peel and core during storage and shelf life pose a challenge for their marketing [4]. It was found that the peel became brown seriously [5] [6]. Similar to other pear cultivars, Huangguan pears were susceptible to deterioration with shriveling, softening, and decay under improper storage conditions. To avoid occurrence of postharvest peel browning, slow cooling was often used in commercially. However, this method was not good for the quality maintenance, and resulted in high rot index and stem shriveling. Alternative novel practices to inhibit peel browning were required for the storage of Huangguan pears.

Considerable research has been conducted on low temperature conditioning (LTC) or cold acclimation in whole plants or other plant tissues, mainly in relation to withstanding winter chill conditions [7] [8]. In many cases, acclimation can reduce lesion development on plant tissues [9] and skin damage [10]. Low temperature conditioning prior to cold disinfestations of "Hass" avocado can effectively eliminate skin damage and improve internal quality [10] [11]. A similar response was found in litchi after low temperature conditioning treatment, which improved subsequent storage behavior and increased the shelf life of fruits after storage [12]. Numerous studies have shown that heat treatment before cold storage of a range of fruit can reduce damage on removal from storage [13]. However, reports on cold conditioning in fruit quality during shelf life were limited.

In view of the successful application of low temperature conditioning (LTC) treatment in loquat fruit [14], zucchini squash [15], avocado fruit [10] [11], and peach [16] [17], LTC was employed to alleviate browning and improve quality of "Huangguan" pears. The effects of LTC on external peel browning and internal quality of Huangguan pears in storage and subsequent shelf life behavior were studied in this paper.

\section{Materials and Methods}

\subsection{Fruits and Low Temperature Conditioning Treatment}

Huangguan pears (Pyrus bretschneideri Rehd cv. Huangguan) were harvested from three pear orchards in Xinji City, Hebei Province, China on 20 August, 2014 and 16 August, 2013. Pears were placed in single layer trays and transported to our laboratory in the same day. Fruit was selected for uniformity of size and appearance. All harvested pears were chosen without diseases, bruises, or injuries.

The fruits were given a low temperature conditioning treatment at $8^{\circ} \mathrm{C}-9^{\circ} \mathrm{C}$ for $1,3,6$, and 9 days, respectively; fruits without LTC treatment were regarded as control. All the fruits were stored in $-1^{\circ} \mathrm{C}-0^{\circ} \mathrm{C}$ for 250 days; Fruits were taken out for browning and quality evaluation every 50 days. To investigate the quality changes in shelf life, shelf trials were undertaken in the temperature of $20^{\circ} \mathrm{C}-25^{\circ} \mathrm{C}$ and humidity of $65 \%-70 \%$. The 20 fruits were used for each of the three replicates.

\subsection{Peel and Core Browning Evaluation}

Peel browning occurrence was calculated by the formula that peel browning occurrence $=$ (peel browning fruits/total fruits) $\times 100 \%$.

Core browning was judged by the method of Veltman et al. [18] and was calculated by the formula that core browning rate $=$ (core browning fruits/total fruits $) \times 100 \%$.

Peel browning index was judged by the surface area browned according to the method of Feng et al. [19] with some modifications. Browning area was recorded as a percentage of the fruit surface and scored on a 4-point scale ( 0 , no browning; 1 , browning area was less than $10 \%$; 2, browning area was ranged in $10 \%-20 \%$; 3 , browning area was ranged in $20 \%-40 \%$; 4 , browning area was more than $40 \%$ ); the amount and severity of pear peel browning was expressed by an index, which was calculated by the following formula:

peel browning index $=\sum$ (browning classification level $\times$ fruits at that level $) /($ total fruits $\times$ the highest level $)$. 


\subsection{Core Breakdown Rate}

Core breakdown was judged by the method of Kadam et al. [20] and core breakdown rate was calculated by the formula that tissue disorder rate $=($ core breakdown fruits/total fruits $) \times 100 \%$.

\subsection{Total Soluble Solids, Titratable Acidity and Flesh Firmness Measurement}

Five pears per repetition (three repetitions per treatment) were used to determine total soluble solids contents (TSS), titratable acidity (TA) and flesh firmness, initially and during cold storage and shelf life period. TSS was measured individually from the pressed juice of each fruit by means of a hand-held sugar refractometer (WYTJ; Chengdu Optical Apparatus Co. Ltd., China). A previously described method was used to measure TA, and the results were expressed as percentage malic acid [21]. Flesh firmness was determined with fruit firmness. This was determined on two opposite peeled sides at the widest diameter of the pear, using a penetrometer (Wagner, Greenwich, CT, USA, Fruit Test FT Series; FT 327, 0 - 13 kg) fitted with an 8 mm diameter plunger.

\subsection{Sensory Quality Evaluation}

In this experiment, sensory quality parameters, such as pear aroma, flesh juiciness, flesh taste, and crispness, were employed. For taste analysis (acceptability), five fruit per treatment as a pool removed from cold storage and shelf life trial were equilibrated to room temperature $\left(22^{\circ} \mathrm{C}\right)$ for $1 \mathrm{~h}$ before evaluation. They were then cleaned, peeled and cut into wedges for sensory evaluation. 12 panelists (6 men and 6 women; aged 18 - 50 years old) familiar with sensory evaluation procedures, and consuming fresh pears at least twice a month performed the evaluation. All possible combinations were used for each panelist.

Sensory quality evaluation was subsequently performed, and the quality was according to the methods of Deng et al. [22] with some modifications that scored on a 4-point scale (3, excellent; 2, good; 1, poor; 0, extremely poor). Three different pooled flesh samples of pears of each treatment were presented to panelists in random order. Each sample was identified with a three-digit number. Panelists rated samples in individual rooms under incandescent light. Palates were cleansed with bottled water between samples.

\subsection{Malondialdehyde (MDA) Content}

MDA content was assayed using the method of Pongprasert et al. [23] with a slight modification. Pear peel (5 g) was homogenized in $25 \mathrm{ml} \mathrm{5 \%} \mathrm{(w/v)} \mathrm{trichloroacetic} \mathrm{acid} \mathrm{(TCA).} \mathrm{The} \mathrm{mixture} \mathrm{was} \mathrm{centrifuged} \mathrm{for} 15 \mathrm{~min}$ at $4000 \times$ g. To $1.5 \mathrm{ml}$ of the supernatant was added $2.5 \mathrm{ml} \mathrm{0.5 \% (w/v)} \mathrm{thiobarbituric} \mathrm{acid} \mathrm{(TBA)} \mathrm{in} \mathrm{15 \%} \mathrm{TCA.}$ The reaction solution was held for $20 \mathrm{~min}$ in a boiling water bath, cooled quickly, and centrifuged at 12,000 $\times \mathrm{g}$ for $10 \mathrm{~min}$ to clarify the solution. Absorbance was measured at $532 \mathrm{~nm}$ and corrected for non-specific turbidity by subtracting the absorbance at $600 \mathrm{~nm}$, calculated with an extinction coefficient of $1.55 \mathrm{nmol} /(\mathrm{l} . \mathrm{m})$, and expressed as nmol/g FW.

\subsection{Ethanol Content}

Ethanol levels in pears were determined according to the method as described by Chervin et al. [24] using a Chrompack (HP, USA) HP5890A gas chromatograph, with a back flush. Detector: $\mathrm{N}_{2}$-stabilized FID, columns: a WCOT fused silica $25 \mathrm{~m} \times 0.53 \mathrm{~mm}$ ID, CP sil 5CB pre-column, and a WCOT fusef silica $50 \mathrm{~m} \times 0.53 \mathrm{~mm}$ ID, CP sil 8 CB column. The carrier gas was helium (flow $30 \mathrm{ml} / \mathrm{min}$ ).

\subsection{Statistical Analysis}

Data were reported as mean \pm SD for triplicate determinations. Analysis of variance and least significant difference tests (SPSS 17.0 for Windows, 1999, SPSS Inc., Chicago, IL) were conducted to identify differences among means, while a Pearson correlation test was conducted to determine the correlations among means. Statistical significance was declared at $P<0.05$.

\section{Results}

\subsection{Peel Browning in Storage}

The peel browning after LTC treatment during storage period was shown in Figure 1 and Figure 2. It can be 


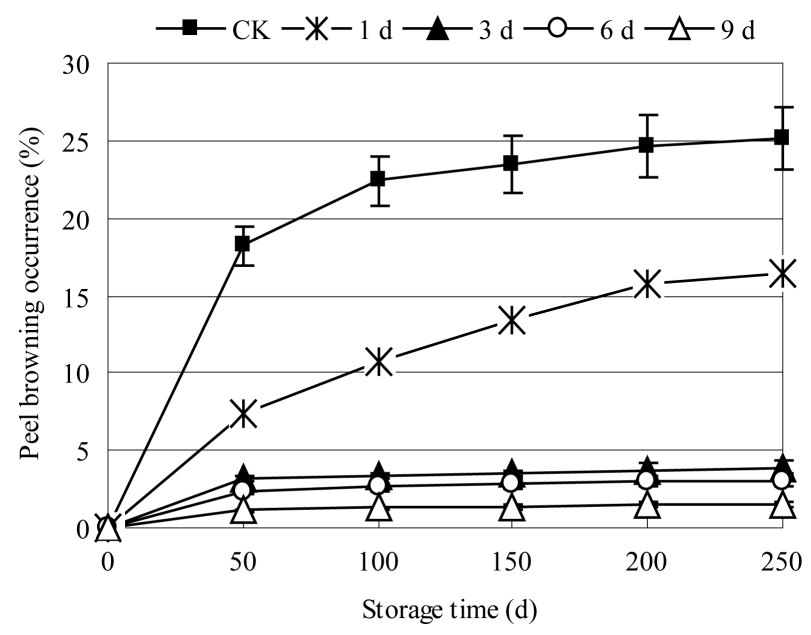

Figure 1. Effects of low temperature conditioning (LTC) on peel browning occurrence of Huangguan pears. Each value represents mean \pm standard deviation of three replicates.

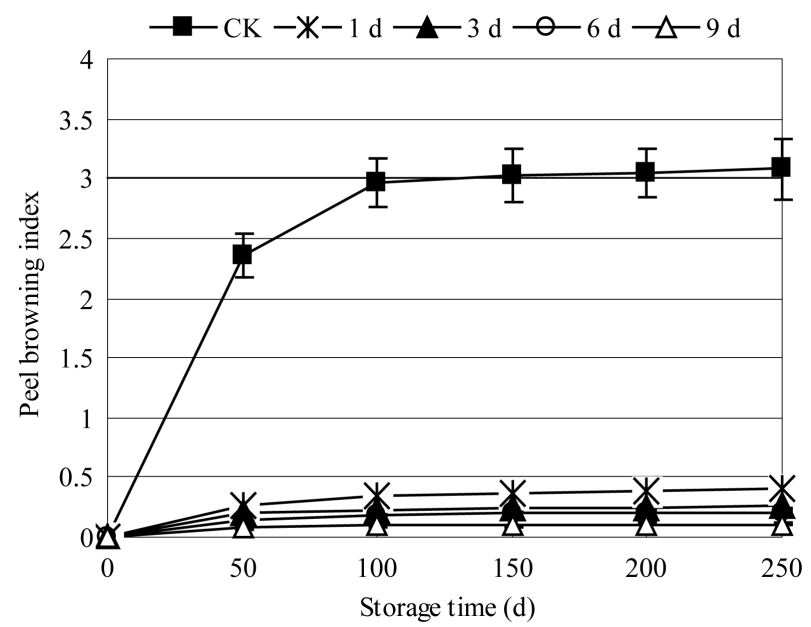

Figure 2. Effects of LTC on peel browning index of Huangguan pears during storage. Each value represents mean \pm standard deviation of three replicates.

seen that peel browning occurrence in the control showed a sharp increase in the initial 50 days of storage, then gradually increased after that, and the level was more than $25 \%$; in the contemporary, peel browning occurrence of pears treated by LTC for $1 \mathrm{~d}$ was increased remarkably, reaching $15 \%$ at last; however, peel browning occurrence of LTC for 3, 6, and $9 \mathrm{~d}$ was less than $4 \%$, which was significantly different than that of the control and 1 $\mathrm{d}$ treatment $(P<0.05)$, although, no significant differences in these three treatments were found $(P>0.05)$.

For peel browning index, all treatments showed a more lower value than that of the control $(P<0.05)$ where the peel browning index reached about 0.3 , whereas, every treatment was less than 0.05 .

Peel browning was a key limited factor influencing Huangguan pears marketing [4] [5]. The above results indicated LTC treatment was efficiently to control peel browning of Huangguan pears, and treatment for 3 , 6 , and 9 days was more effective.

\subsection{Core Browning in Shelf Life}

As shown in Figure 3, core browning appeared in samples of the control and treatment of LTC for $1 \mathrm{~d}$ after storage and core browning rate was $16.68 \%, 18.32 \%$, respectively, but no significant different was found between them $(P>0.05)$; although no visible core browning in other treatments was found. After $12 \mathrm{~d}$ in shelf life, the 


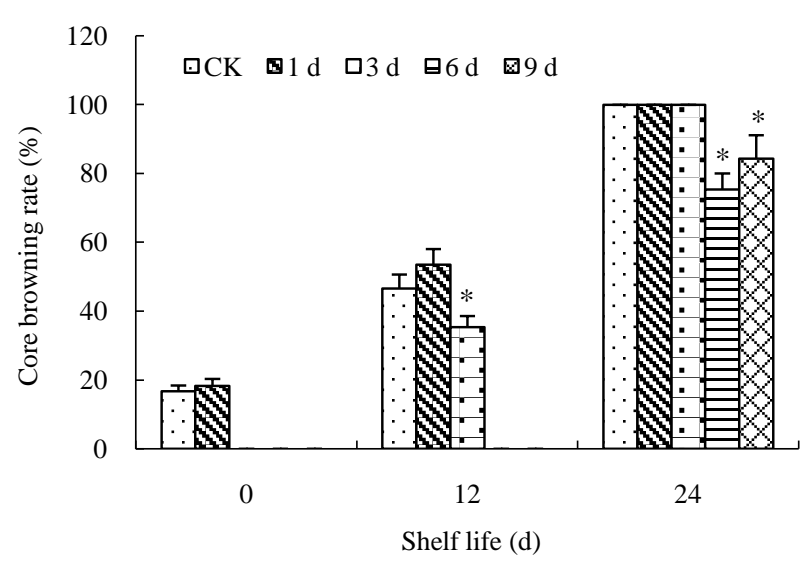

Figure 3. Effects of LTC on core browning of Huangguan pears in shelf life. Each value represents mean \pm standard deviation of three replicates and “*” meant significant difference $(P<0.05)$.

core browning increased remarkably. Core browning rate was $46.6 \%, 53.5 \%, 35.3 \%$ for the control, LTC for $1 \mathrm{~d}$ and $3 \mathrm{~d}$, respectively; however, core browning rate by treatment of LTC for $3 \mathrm{~d}$ was much less than that of control and LTC for $1 \mathrm{~d}(P<0.05)$, and no core browning can be seen by treatment of LTC for $6 \mathrm{~d}$ and $9 \mathrm{~d}$. At the end of test for shelf life, $24 \mathrm{~d}$, severe core browning was found in all treatments. Core browning appeared in all pears by treatment of LTC for $1 \mathrm{~d}, 3 \mathrm{~d}$ and the control; and for LTC for $6 \mathrm{~d}$ and $9 \mathrm{~d}$. The core browning rates reached $75.36 \%$ and $84.34 \%$, respectively, which was significant different from the other three treatments $(P<$ 0.05 ).

The results showed that core browning occurrence of Huangguan pears in shelf life (about $22^{\circ} \mathrm{C}$ ) was inevitable, although LTC treatment slowed the trend. In addition, treatments with longer time was more effective than relative short time, especially for $6 \mathrm{~d}$ and $9 \mathrm{~d}$, and treatment for $6 \mathrm{~d}$ showed a best efficiency in inhibiting core browning; however, treatment for $1 \mathrm{~d}$ was the worst, even higher than the control, which indicated that treatment time was an important factor influencing the efficiency of LTC to inhibit core browning of Huangguan pears. This result was in agreement with those found by Woolf et al. [11] [25] and Hofman et al. [10] that LTC response was time and temperature dependant.

\subsection{Core Breakdown in Shelf Life}

As listed in Table 1, core breakdown was observed in the control, and no visible core breakdown was appeared in the four LTC treatments. The results indicated that LTC inhibited the occurrence of core breakdown, alleviated the tissue darkening or softening, which was in accordance with results of core browning rate showed in Figure 3.

\subsection{Firmness, Total Soluble Solids Contents (TSSC) and Titratable Acidity (TA)}

It can be seen from Figure 4 that firmness of Huangguan pears decreased gradually in storage period, till $250 \mathrm{~d}$, firmness of control was $3.58 \mathrm{~kg} \cdot \mathrm{cm}^{-2}$, whereas LTC treatment maintained higher firmness that was 3.78, 3.90, 4.02, and $4.03 \mathrm{~kg} \cdot \mathrm{cm}^{-2}$ for $1,3,6$ and $9 \mathrm{~d}$, respectively, although no significant difference was found between them $(P>0.05)$. While in shelf life, firmness increased until $12 \mathrm{~d}$, then, declined, which may be the reason of quick decreasing of flesh juiciness (seen in Table 2) or lignification with senescence of the initial shelf life, thereafter declined with the tissue softening and quality deterioration.

It can be seen from Figure 5 that TSS content in storage increased till $100 \mathrm{~d}$, then, declined. In shelf life, TSS content changed a little except for. Whether in storage or shelf life, TSS content of LTC treatment for 3, 6 and 9 $\mathrm{d}$ had no significant difference from that of the control $(P>0.05)$.

Titratable acid of Huangguan pears in storage influenced by LTC was shown in Figure 6. It can be seen that titratable acid increased in the initial, then, declined in all treatments. For the control, titratable acid changed remarkably. The highest value was reached at $50 \mathrm{~d}$, than that of LTC, and then declined quickly until at 200 and 
$250 \mathrm{~d}$, the value was the lowest. Relative small changes were found in LTC treatments for 3 and $6 \mathrm{~d}$, and the values were $0.144 \%$ and $0.140 \%$, respectively, which showed significant difference to the control $(P<0.05)$. Results indicated that LTC treatments played a positive role in inhibiting reduction of titratable acid and maintaining at a relative high level.

Table 1. Effects of LTC on core breakdown of Huangguan pears in shelf life. Each value represents mean \pm standard deviation of three replicates and different letters in the same row meant significant difference $(P<0.05)$.

\begin{tabular}{ccc}
\hline LTC & Shelf life for $12 \mathrm{~d}$ & Shelf life for $24 \mathrm{~d}$ \\
\hline CK & 0 & $6.67 \pm 1.33 \mathrm{a}$ \\
$1 \mathrm{~d}$ & 0 & 0 \\
$3 \mathrm{~d}$ & 0 & 0 \\
$6 \mathrm{~d}$ & 0 & 0 \\
$9 \mathrm{~d}$ & 0 & 0 \\
\hline
\end{tabular}

Core breakdown meant tissue browning or softening in and around the core.

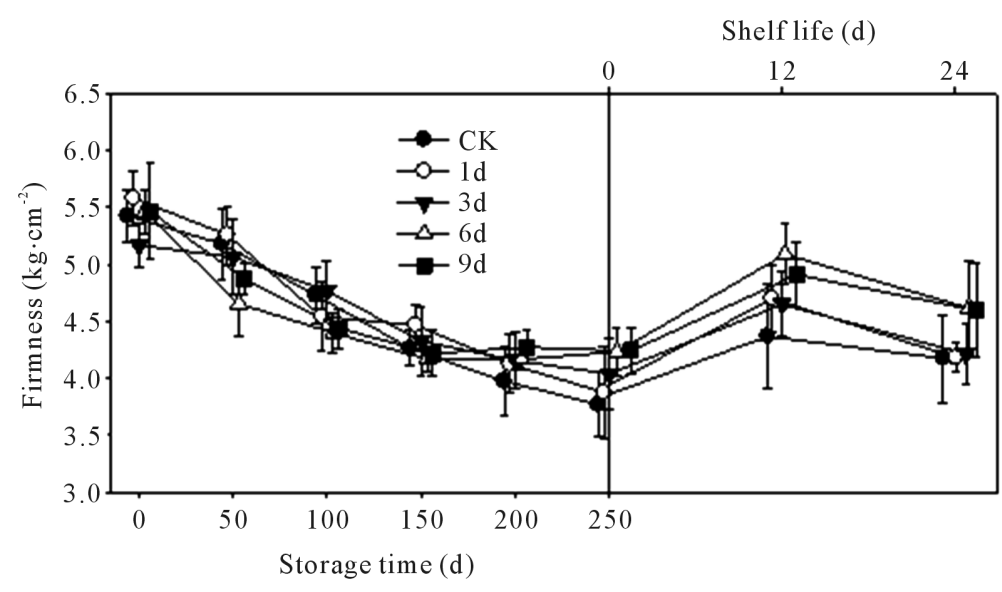

Figure 4. Effects of LTC on firmness of Huangguan pears in storage period and shelf life. Each value represents mean \pm standard deviation of three replicates.

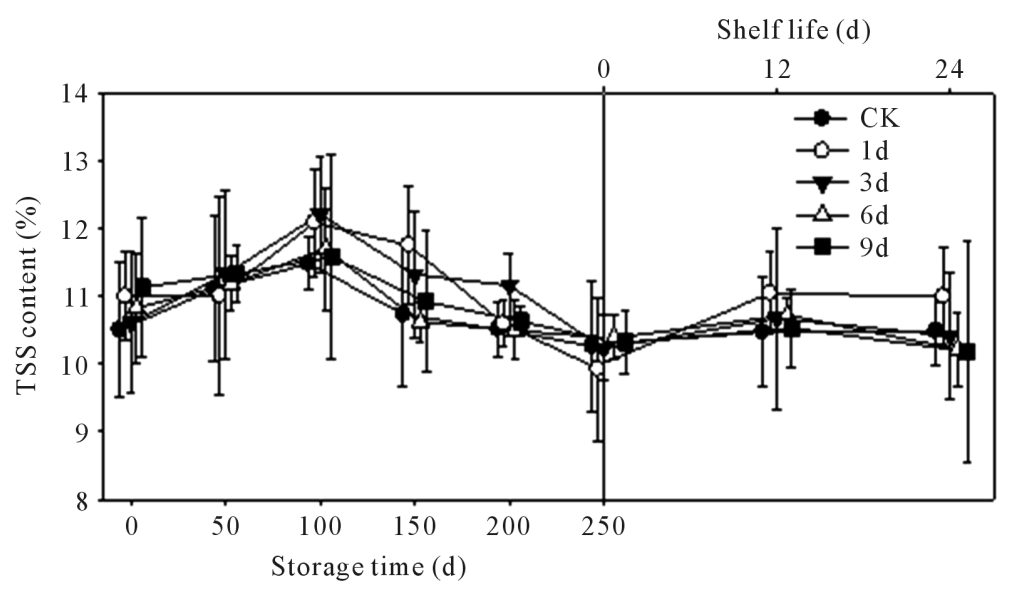

Figure 5. Effects of LTC on TSS content of Huangguan pears in storage period and shelf life. Each value represents mean \pm standard deviation of three replicates. 
Table 2. Effects of LTC on sensory quality of Huangguan pears in storage and shelf life. Each value represents mean \pm standard deviation of three replicates, higher value meant better quality and different letters in the same row meant significant difference $(P<0.05)$.

\begin{tabular}{|c|c|c|c|c|c|}
\hline \multicolumn{2}{|c|}{ LTC treatment } & \multirow{2}{*}{$\begin{array}{c}\text { Fruit aroma } \\
\qquad 3 a\end{array}$} & \multirow{2}{*}{$\begin{array}{l}\text { Flesh juiciness } \\
\qquad 2.43 \pm 0.24 a\end{array}$} & \multirow{2}{*}{$\begin{array}{c}\text { Taste } \\
2.23 \pm 0.21 \mathrm{a}\end{array}$} & \multirow{2}{*}{$\begin{array}{c}\text { Crispness } \\
1.74 \pm 0.19 a\end{array}$} \\
\hline & $\mathrm{CK}$ & & & & \\
\hline & LTC for $1 \mathrm{~d}$ & 3a & $2.56 \pm 0.17 a$ & $2.28 \pm 0.14 a$ & $1.64 \pm 0.12 \mathrm{a}$ \\
\hline \multirow[t]{5}{*}{$250 \mathrm{~d}$} & LTC for $3 \mathrm{~d}$ & За & $2.58 \pm 0.18 a$ & $2.26 \pm 0.16 a$ & $1.66 \pm 0.13 a$ \\
\hline & LTC for $6 \mathrm{~d}$ & $3 a$ & $2.56 \pm 0.22 \mathrm{a}$ & $2.29 \pm 0.20 \mathrm{a}$ & $1.66 \pm 0.19 a$ \\
\hline & LTC for $9 \mathrm{~d}$ & 3a & $2.55 \pm 0.25 a$ & $2.32 \pm 0.17 a$ & $1.67 \pm 0.14 \mathrm{a}$ \\
\hline & CK & $2.28 \pm 0.17 a$ & $1.14 \pm 0.06 b$ & $1.02 \pm 0.08 \mathrm{ab}$ & $0.92 \pm 0.11 b$ \\
\hline & LTC for $1 \mathrm{~d}$ & $2.26 \pm 0.19 a$ & $1.13 \pm 0.07 b$ & $0.99 \pm 0.07 b$ & $0.85 \pm 0.09 b$ \\
\hline \multirow[t]{3}{*}{$250 d+24 d$} & LTC for $3 \mathrm{~d}$ & $2.23 \pm 0.19 a$ & $1.04 \pm 0.18 b$ & $0.91 \pm 0.11 b$ & $0.89 \pm 0.17 b$ \\
\hline & LTC for $6 \mathrm{~d}$ & $2.40 \pm 0.21 \mathrm{a}$ & $1.39 \pm 0.12 \mathrm{a}$ & $1.19 \pm 0.13 a$ & $1.32 \pm 0.12 \mathrm{a}$ \\
\hline & LTC for $9 \mathrm{~d}$ & $2.23 \pm 0.07 a$ & $1.19 \pm 0.15 a b$ & $1.04 \pm 0.06 a$ & $0.91 \pm 0.14 b$ \\
\hline
\end{tabular}

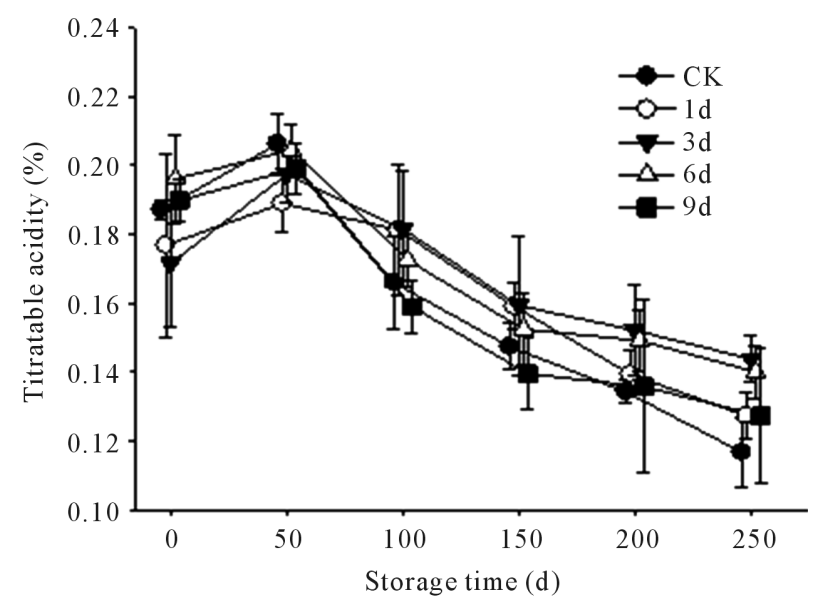

Figure 6. Effects of LTC on titratable acid of Huangguan pears in storage period. Each value represents mean \pm standard deviation of three replicates.

\subsection{MDA Content}

In storage period, MDA content increased gradually with no distinct difference between all treatments $(P>$ 0.05). With longer shelf life, MDA content showed a marked increase; at $12 \mathrm{~d}$, MDA content in LTC treatments was lower than the control, however, at $24 \mathrm{~d}$, only treatments for 3 and $6 \mathrm{~d}$ were lower than the control (Figure 7). Results showed LTC treatments would cause damage to the pear peel, increased the permeability of cell membrane, although the effect was minimal in cold storage. But in shelf life, LTC treatment showed a positive role in inhibiting MDA production.

\subsection{Ethanol Content}

Ethanol accumulation would cause browning in "Bartlett" pears [26], although it was not the direct cause of tissue browning in apples [27] [28]. Ethanol content increased in storage and shelf life overall (Figure 8). At $150 \mathrm{~d}$ of storage, ethanol content of LCT treatments was higher than the control. At $200 \mathrm{~d}$ of storage, ethanol content of LCT treatments for 6 and $9 \mathrm{~d}$ was lower than the control; at termination of storage, ethanol content was 0.67 , $0.63,0.33$, and $0.49 \mu \mathrm{mol} / \mathrm{g}$ of LCT treatment for $1,3,6$, and $9 \mathrm{~d}$, respectively, which was much lower than the 


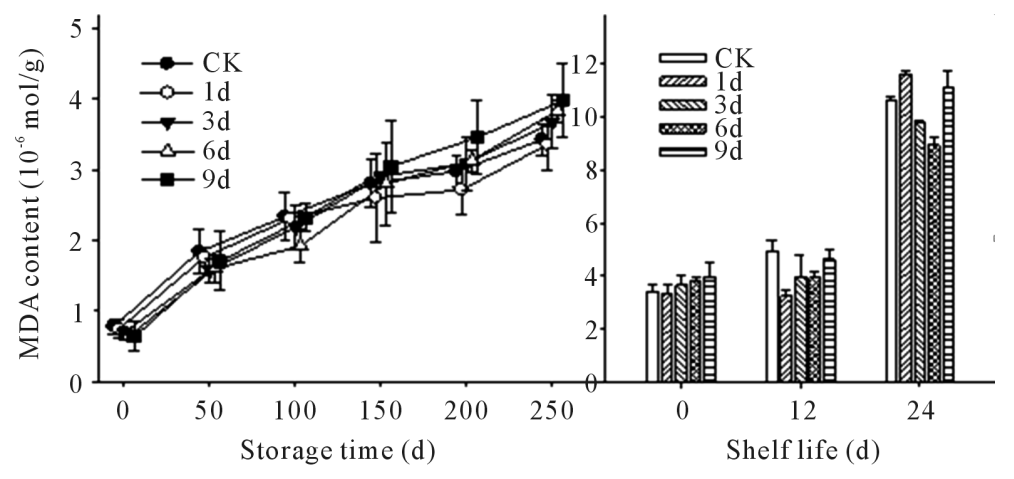

Figure 7. Effects of LTC on malondialdehyde content of Huangguan pears in storage period. Each value represents mean \pm standard deviation of three replicates.

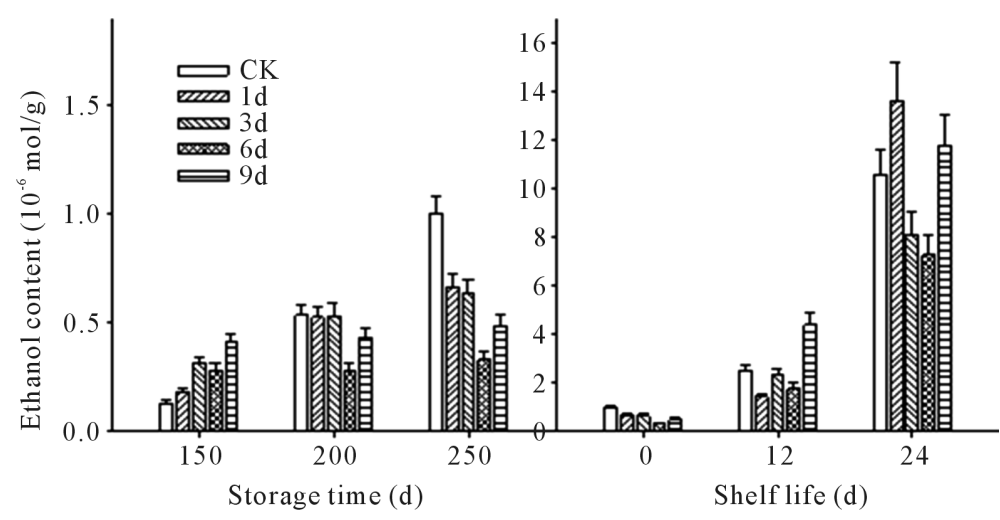

Figure 8. Effects of LTC on ethanol content of Huangguan pears in storage. Each value represents mean \pm standard deviation of three replicates.

control $(P<0.05)$. In shelf life, LCT treatments redcued the production of ethanol for LCT treatments for 3 and $6 \mathrm{~d}$, but not for treatments of 1 and $9 \mathrm{~d}$.

\subsection{Sensory Quality}

It can be seen from Table 2 that at $250 \mathrm{~d}$ of storage, fruit aroma, juiciness, taste and crispness changed a little. Sensory quality of pears was maintained for control and LTC treatment and no significant different was found between them $(P<0.05)$. At $24 \mathrm{~d}$ of shelf life, odor was found in all treatments, although values were not significantly different $(P>0.05)$. For flesh juiciness, LTC treatment for 1 and $3 \mathrm{~d}$ was lower than the control, whereas on 6 and $9 \mathrm{~d}$ was much higher $(P<0.05)$. Taste values declined remarkably except for 6 and $9 \mathrm{~d}$ treatment and crispness of $6 \mathrm{~d}$ treatment was better than the control $(P<0.05)$. Others were not significantly different $(P>$ 0.05). Results indicated LTC treatment had minimal influence for sensory quality of Huangguan pears in storage, and in shelf life, LTC treatment for $6 \mathrm{~d}$ was favored to maintain quality of fruits, especially for flesh juiciness and crispness.

\section{Discussions}

Browning is an important disorder of pear fruit which can lead to considerable economic losses [29]. Because of the thin peel, crisp flesh and rich juice, rapid postharvest peel browning of Huangguan pears has been the key limiting factor influencing Huangguan pears marketing [4] [5]. In this paper, disorders of peel browning, core browning (flesh breakdown upon $1 \mathrm{~cm}$ from the peel, [30]) and core breakdown (browning/softening in and around the core, [20]) were investigated by the effect of LTC treatment. Results indicated that LTC would alleviate the occurrence of disorders of Huangguan pears in storage and shelf life (see in Figures 1-3 and Table 1), especially for the inhibition of peel browning, which was of critical point influencing Huangguan pears' mar- 
keting. In addition, results showed that core browning and core breakdown classified as "senescence related" [30] [31] was lowered by LTC treatment (see in Figure 3 and Table 1), which indicated that LTC treatment could delay the senescence process of pears. The above results indicated that LTC treatments inhibited the activity of enzymes involved in fermentative and oxidative metabolism in tissue [30].

The results of this study show that LTC treatment can effectively eliminate skin damage and improve internal quality in storage and shelf life, such as Woolf et al. [11] and Holfman et al. [10] also found that LTC prevented skin damage, manifested as discrete dark patches on the skin, after 3 weeks at $0^{\circ} \mathrm{C}$. This suggests that LTC can provide very effective protection against damage during short duration storage at very low temperatures. Li et al. [12] reported similar responses in litchi, where pre-treatment of fruits at $5^{\circ} \mathrm{C}$ for 5 days improved subsequent storage behavior at $1^{\circ} \mathrm{C}$ and increased the shelf life of fruits after storage. Other reports on LTC in fruit are limited, but numerous studies have shown that heat treatment before cold storage of a range of fruit can reduce damage on removal from storage [13]. Considerable research has been conducted on LTC or cold acclimation in whole plants or other plant tissues, mainly in relation to withstanding winter chill conditions [7] [8]. In many cases, acclimation can reduce lesion development on plant tissues [9] similar to the skin damage noted in the present study.

Woolf et al. [25] found that the LTC response is time and temperature dependent, and conditioning development varied with time and temperature. Woolf et al. [11] and Holfman et al. [10] found the optimal LTC treatments were $6^{\circ} \mathrm{C}-8{ }^{\circ} \mathrm{C}$ for 3 - 5 days, They also found that $4{ }^{\circ} \mathrm{C}$ could be as effective as $6^{\circ} \mathrm{C}-8^{\circ} \mathrm{C}$ if longer conditioning periods are used, as found by Woolf et al. [10]; in litchi, the best temperature identified was $5^{\circ} \mathrm{C}$ [12], although some flexibility in the temperatures and durations were found by Woolf et al. [11]. In this paper, the best outcome was obtained by LTC treatment for $6 \mathrm{~d}$ at $8^{\circ} \mathrm{C}-9^{\circ} \mathrm{C}$, which could be regarded as the optimum in the present study. Higher rot incidence was found by LTC treatment than the control in shelf life, which meant lower temperature $\left(<8^{\circ} \mathrm{C}\right)$ treatment should be used and combinations of different time and temperature should be employed in further study to approach better results. However, the benefits of LTC need to be confirmed under local conditions.

\section{Conclusion}

Our results showed that LTC can effectively alleviate peel browning and physiological disorder of Huangguan pears in storage and shelf life, maintain sensory quality in shelf life and LTC treatment for $6 \mathrm{~d}$ was the optimum condition in the present study. Results indicated that LTC can be used to provide an effective commercial pretreatment before storage with acceptable external and internal quality of Huangguan pear fruit. However, combinations of time and temperature should be employed in further study and benefits of LTC need to be confirmed under local conditions.

\section{References}

[1] Zhao, K.J., Li, J.K., Zhang, P., Zhao, L.Q., Huang, Y.F. and Sun, X.F. (2008) Effect of 1-MCP Treatment on the Occurrence of “Jizhua” Disease and Storage Quality of Huangguan Pear. Storage \& Process, 3, 13-16.

[2] Xiao, C.L., Zhu, L.W., Luo, W., Song, X.Y. and Deng, Y. (2010) Combined Action of Pure Oxygen Pretreatment and Chitosan Coating Incorporated with Rosemary Extracts on the Quality of Fresh-Cut Pears. Food Chemistry, 121, 10031009. http://dx.doi.org/10.1016/j.foodchem.2010.01.038

[3] Feng, Y.X., Li, L.M., Guan, J.F., Ji, H. and Sun, Y.I. (2008) Effect of Functional Modified Atmosphere Packaging on Storage Quality and Browning of Huangguan Pear. Journal of Hebei Agricultural Sciences, 11, 16-17, 32.

[4] Guan, J.F. (2008) Influencing Factors and Occurrence Mechanism of Fruit Brown Spot on Bagged Huangguan Pear Fruit. Deciduous Fruits, 5, 15-18.

[5] Gong, X.M., Guan, J.F., Zhang, J.S., Ji, H., Feng, Y.X., Li, L.M. and Sun, Y.L. (2009) Effects of Calcium and Boron on Quality and Browning Spot Disease of Huangguan Pear. Plant Nutrition and Fertilizer Science, 4, 942-947.

[6] Gong, X.M., Guan, J.F. and Zhang, J.S. (2010) Effects of Postharvest 1-MCP and Calcium Treatments on the Quality and Skin Browning Spot Incidence of Huangguan Pear Fruit. Acta Horticulturae Sinica, 3, 375-382.

[7] Hamman, R.A., Dami, I.E., Walsh, T.M. and Stushnoff, C. (1996) Seasonal Carbohydrate Changes and Cold Hardiness of Chardonnay and Riesling Grapevines. American Journal of Enology and Viticulture, 47, 31-36.

[8] Palonen, P., Buszard, D. and Donnelly, D. (2000) Changes in Carbohydrates and Freezing Tolerance during Cold Acclimation of Red Raspberry Cultivars Grown in Vitro and in Vivo. Physiologia Plantarum, 110, 393-401. 
http://dx.doi.org/10.1034/j.1399-3054.2000.1100314.x

[9] Ciardi, J.A., Deikman, J. and Orzolek, M.D. (1997) Increased Ethylene Synthesis Enhances Chilling Tolerance in Tomato. Physiologia Plantarum, 101, 333-340. http://dx.doi.org/10.1111/j.1399-3054.1997.tb01005.X

[10] Hofman, P.J., Stubbings, B.A., Adkins, M.F., Corcoran, R.J., White, A. and Woolf, A.B. (2003) Low Temperature Conditioning before Cold Disinfestations Improves "Hass" Avocado Fruit Quality. Postharvest Biology and Technology, 28, 123-133. http://dx.doi.org/10.1016/S0925-5214(02)00175-8

[11] Woolf, A.B., Cox, K.A., White, A. and Ferguson, I.B. (2003) Low Temperature Conditioning Treatments Reduce External Chilling Injury of "Hass” Avocados. Postharvest Biology and Technology, 28, 113-122. http://dx.doi.org/10.1016/S0925-5214(02)00178-3

[12] Li, P., Wang, Y.R., Chen, Y.Z., Li, S. and Liu, H.X. (1989) Effect of Cold Hardening of Litchi Fruit on Prolonging Its Cold Storage Life after Harvest. Acta Botanica Austro Sinica, 4, 143-151.

[13] Lurie, S. (1998) Postharvest Heat Treatments. Postharvest Biology and Technology, 14, 257-269. http://dx.doi.org/10.1016/S0925-5214(98)00045-3

[14] Cai, C., Chang, J.X., Lan, L.S., Li, X., Zhou, C.H., Zhang, W.S., Ferguson, I. and Chen, K.S. (2006) Low Temperature Conditioning Reduces Postharvest Chilling Injury in Loquat Fruit. Postharvest Biology and Technology, 41, 252-259. http://dx.doi.org/10.1016/j.postharvbio.2006.04.015

[15] Wang, C.Y. (1994) Combined Treatment of Heat Shock and Low Temperature Conditioning Reduces Postharvest Chilling Injury in Zucchini Squash. Postharvest Biology and Technology, 4, 65-73. http://dx.doi.org/10.1016/0925-5214(94)90008-6

[16] Cai, Y., Yu, M.L., Xing, H.J., Di, H.T., Pei, J.Y., Xu, F. and Zheng, Y.H. (2010) Effects of Low Temperature Conditioning on Chilling Injury and Quality of Cold-Stored Juicy Peach Fruit. Transactions of the CSAE, 26, 334-338.

[17] Jin, P., Wang, K.T., Shang, H.T., Tong, J.M. and Zheng, Y.H. (2009) Low Temperature Conditioning Combination with Methyl Jasmonate Treatment Alleviate Chilling Injury of Peach Fruit. Journal of the Science of Food and Agriculture, 89, 1690-1696. http://dx.doi.org/10.1002/jsfa.3642

[18] Veltman, R.H., Kho, R.M., van Schaik, A.C.R., Sanders, M.G. and Oosterhaven, J. (2000) Ascorbic Acid and Tissue Browning in Pears (Pyrus communis L. cvs Rocha and Conference) under Controlled Atmosphere Conditions. Postharvest Biology and Technology, 19, 129-137. http://dx.doi.org/10.1016/S0925-5214(00)00095-8

[19] Feng, X.Q., Biasi, B. and Mitcham, E.J. (2004) Effects of Various Coatings and Antioxidants on Peel Browning of "Bartlett” Pears. Journal of the Science of Food and Agriculture, 84, 595-600. http://dx.doi.org/10.1002/jsfa.1705

[20] Kadam, S.S., Dhumal, A. and Shinde, N.N. (1995) Pear. In: Salunkhe, D.K. and Kadam, S.S. Eds., Handbook of Fruit Science and Technology, Marcel Dekker Inc., New York, 182-202.

[21] Şumnu, G. (2000) Quality Control Charts for Storage of Pears. European Food Research and Technology, 211, 355359. http://dx.doi.org/10.1007/s002170000190

[22] Deng, Y., Wu, Y. and Li, Y.F. (2005) Effects of High $\mathrm{O}_{2}$ Levels on Postharvest Quality and Shelf Life of Table Grapes during Long-Term Storage. European Food Research and Technology, 221, 392-397. http://dx.doi.org/10.1007/s00217-005-1186-4

[23] Pongprasert, N., Sekozawa, Y., Sugaya, S. and Gemma, H. (2011) A Novel Postharvest UV-C Treatment to Reduce Chilling Injury (Membrane Damage, Browning and Chlorophyll Degradation) in Banana Peel. Scientia Horticulturae, 130, 73-77. http://dx.doi.org/10.1016/j.scienta.2011.06.006

[24] Chervin, C., Truett, J.K. and Speirs, J. (1999) Alcohol Dehydrogenase Expression and Alcohol Production during Pear Ripening. Journal of the American Society for Horticultural Science, 124, 71-75.

[25] Woolf, A.B., Watkins, C.B., Bowen, J.G., Maindonald, J.H., Lay-Yee, M. and Ferguson, I.B. (1995) Reducing External Chilling Injury in Stored "Hass” Avocados with Dry Heat Treatments. Journal of the American Society for Horticultural Science, 120, 1050-1056.

[26] Ke, D., Yahia, E., Mateos, M. and Kader, A.A. (1994) Ethanolic Fermentation of "Bartlett” Pears as Influenced by Ripening Stage and Atmospheric Composition. Journal of the American Society for Horticultural Science, 119, 976-982.

[27] Fernandez-Trujillo, J.P., Nock, J.F. and Watkins, C.B. (2001) Superficial Scald, Carbon Dioxide Injury, and Changes of Fermentation Products and Organic Acids in "Cortland" and "Law Rome” Apples after High Carbon Dioxide Stress Treatment. Journal of the American Society for Horticultural Science, 126, 235-241.

[28] Argenta, L.C., Fan, X. and Mattheis, J.P. (2002) Responses of “Fuji” Apples to Short and Long Duration Exposure to Elevated $\mathrm{CO}_{2}$ Concentration. Postharvest Biology and Technology, 24, 13-24. http://dx.doi.org/10.1016/S0925-5214(01)00120-X

[29] Franck, C., Lammertyn, J., Tri Ho, Q., Verboven, P., Verlinden, B. and Nicolaï, B.M. (2007) Browning Disorders in Pear Fruit. Postharvest Biology and Technology, 43, 1-13. http://dx.doi.org/10.1016/j.postharvbio.2006.08.008 
[30] Larrigaudière, C., Lentheric, I., Puy, J. and Pinto, E. (2004) Biochemical Characterization of Core Browning and Brown Heart Disorders in Pear by Multivariate Analysis. Postharvest Biology and Technology, 31, 29-39. http://dx.doi.org/10.1016/S0925-5214(03)00132-7

[31] Giraud, M., Westercamp, P., Coureau, C., Chapon, J.F. and Berrie, A. (2001) Recognizing Postharvest Diseases of Apple and Pear. Centre Technique Interprofessionel des Fruits et Légumes, Paris. 